\title{
OPINION
}

\section{Rethinking agricultural education}

\author{
Kamyar Enshayan
}

Is it possible to have public agricultural colleges that promote the establishment and maintenance of a permanent, sound and prosperous agriculture and rural life, as mandated by the acts establishing the landgrant colleges (1862), the experiment station system (1887), and Cooperative Extension (1914)? If so, what would they be like? What kinds of educational programs would they offer students to create an enduring agriculture and avoid the prevailing tolerance for our existing system of food and agriculture, which demeans rural people and degrades the land?

\section{Basic Assumptions}

Recent investigations into cognition and learning can provide new conceptual frameworks for agricultural education. It is now clear that "knowledge is situated, being in part a product of the activity, context, and culture in which it is developed and used" (Brown et al., 1989). This implies that what is learned cannot be separated from how or where it is learned. One implication is that what is learned by the students and faculty in most agricultural schools is fundamentally different from what is learned in farm communities and rural places. The former learning, for the most part, is embedded in the culture of departmentalized thinking, a "reductionistic-science-is-the-answer" mindset, refereed journals, and an unhealthy sense of know-it-allness. The latter learning, on the

A preliminary version of this article was published in Organic Farmer, Fall, 1992.

Kamyar Enshayan is the education coordinator for the Sustainable Agriculture Program, Ohio State University, 1735 Neil Ave., Columbus, $\mathrm{OH} 43210$. other hand, is rooted in experience, years of trial and error, community, economy, and familiarity with a particular landscape.

Most agricultural colleges think of themselves as "custodians and preservers of knowledge. This creates the image of knowledge as a commodity that can be stored or warehoused and then dispensed or given (usually by a lecture) to a recipient (a student)" (Ison, 1990). Research in learning challenges this attitude and practice. We are now realizing that knowledge cannot just be handed over or transmitted, but must be built anew by each learner with a supportive teacher who leads from behind (Wells, 1989; McCutcheon and Jung, 1990). We now know that farmers and students are participants and active constructors of their own knowledge (Chambers et al., 1989; Haverkort et al., 1991).

Agricultural education for a sustainable agriculture should emphasize learning rather than teaching. A rich learning environment for agriculture faculty and students alike has to involve all of agriculture: the landscape, farms, farmers, traditions, and culture. If we begin to see that "research is not a process of proving something, but a process of discovering and learning" (Ray, 1987), we may see problem solving, thinking, learning, research, and discovery as the same process. This rethinking would entail abandoning our way of viewing teaching, research and extension as separate.

\section{Specific Programs}

Here are a few ideas for agricultural schools, whether private or public, that wish to create a learning environment for a sustainable agriculture:

History of agriculture. This theme is rarely included in the courses of agricul- tural schools, but it is so crucial for all of us to learn from our agricultural past.

Key ideas in conservation and sustainable agriculture. Students of agriculture need to know who has said what. Students and faculty must be aware of the key ideas presented by anthropologists, historians, poets, philosophers, conservationists and many past and contemporary scholars who have outlined agriculture's problems and prospects.

Farmers-in-residence. In law schools and medical schools, practitioners are invited to work with students, to teach, and to share their experiences. We ought to do the same in agricultural schools.

Farm apprenticeships. The best place to learn farming is on the farm. Ideally, it will greatly benefit both the farmer and the apprentice.

Community-building apprenticeships. Agriculture students should spend time as interns with the key rural development and sustainable agriculture organizations in their region.

Agricultural ecology. Students should undertake a series of studies dealing with landscape ecology, agricultural energy, soil ecology, nutrient cycling, recycling and other fundamentals of ecology.

Faculty-student farm. Sustainable agriculture education in universities must, among other things, be formulated around a faculty/student-run working farm. Both faculty and students should be involved in the labor and planning. Working on such a farm can inspire important research questions and provide a firsthand opportunity for students and faculty to put into practice their ideas for ecological soundness, soil improvement and economic vitality.

Direct involvement in the regional food economy. The faculty/student-run farm should participate in local markets so that 
students and faculty think through and understand how agricultural policies affect the local and international food economy.

Exploring the appropriate balance be tween food self-reliance and trade. Why should Ohio's landscape be covered with corn and soybeans for export, with their accompanying soil erosion scars, while we import tasteless food from Califomia and other distant places? How much food trade is OK? These and many other questions are extremely important for everyone to think through.

Forums on current and long-term agricultural issues/problems. There should be frequent public forums and debates held at agricultural schools exploring important current issues such as the Farm Bill, GATT, roots of rural decline, rural-city partnership, etc. Agricultural schools should be facilitators for such debate and dialogues.

Understanding the human element of agriculture. Agriculture involves more than soil chemistry equations and agricultural economics; it involves people, cul- tural traditions, stewardship ethics, communities, stories, memories. Agricultural education for sustainability should weave these together.

Until now, these educational elements have been provided mostly through private non-profit sustainable agriculture research and education institutions, rural development organizations, and farmer-run associations. The sustainable agriculture programs in agricultural universities, liberal arts colleges, and other agricultural institutions are growing in number and maturity, and have a wealth of talents to create learning environments for a sustainable agriculture.

\section{References}

1. Brown, J.S., A. Collins, and P. Duguid. 1989. Situated cognition and the culture of learning. Educational Researchers 18(1):32-42.

2. Chambers, R., A. Pacey, and L.A. Thrupp (eds). 1989. Farmer First:
Farmer Innovation and Agricultural Research. Intermediate Technology Publications, London, England.

3. Haverkort, B., J. van der Kamp, and A. Water-Bayers. 1991. Joining Farmers' Experiments: Experiences in Participatory Technology Development. Intermediate Technology Publications, London, England.

4. Ison, R.L. 1990. Teaching threatens sustainable agriculture. Gatekeeper Series No. 21. International Institute for Environment and Development, London, England.

5. McCutcheon, G., and B. Jung. 1990. Alternative perspectives on action research. Theory into Practice 29(3): 144-151.

6. Ray, L.C. 1987. Reflections on classroom research. In D. Goswami and P.R. Stillman (eds). Reclaiming the Classroom. Heineman, Portsmouth, New Hampshire. pp. 7-36.

7. Wells, G. 1989. Foreword. In G.S. Pinnell and M.L. Matllin (eds). Teachers and Researchers. International Reading Assoc., Newark, Delaware.

\section{UPCOMING EVENTS}

February through March 18, sustainable agriculture field days will be held throughout Wisconsin; for details, contact Wisconsin Dept. of Agriculture, Trade and Consumer Protection, 801 W. Badger Rd., PO Box 8911, Madison, WI 53709-8911; (608)262-6429 or (608)625-2602.

February 18-21, the second Organic Farm Fresh Table Top Exhibit will be held in conjunction with Natural Products Expo West '93 in Anaheim, CA; contact Steven Hoffman, New Hope Communications, 1301 Spruce St., Boulder, CO 80302; (303)939-8440.

February 23-25, Silage Production from Seed to Animal, sponsored by the Northeast Regional Agricultural Engineering Service, will be held in Syracuse, N.Y; contactNRAES, 152 Riley-Robb Hall, Cooperative Extension, Ithaca, N.Y. 148535701; (607)255-7654.
February 23-26, Preserving Our Environment: The Race Is On, the 24th Annual International Erosion Control Association conference and trade exposition, will be held in Indianapolis, IN; contact IECA, P.O. Box 4904, Steamboat Springs, CO 80477-4904; (303)879-3010.

February 26-27, An American Farmer Can Feed a Nation, But Can He Feed His Family?, a sustainable agriculture conference sponsored by Central Colorado Water Conservancy District Sustainable Agriculture Project, will be held in Greeley, CO; contact CCWCD, 3209 West 28th St., Greeley, CO 80631; (303)3304540.

February 27, the annual meeting of the Nebraska Sustainable Agriculture Society will be held at Central Community College-Platte Campus near Columbus, NE; contact NSAS, Box 736, Hartington, NE 68739; (402)254-2289.
February 27-28, the 14th annual Ohio Organic Conference will be held at the Agricultural Technical Institute, Wooster, OH; contact Ohio Ecological Food and Farm Association, 65 Plymouth St., Plymouth, OH 44865; (419)687-7665.

March 1, Alternative Agriculture Policy: ANew Time to Choose, the 10th annual conference of the Institute for Alternative Agriculture, will be held in Washington, D.C.; contact the IAA, 9200 Edmonston Road, \#117, Greenbelt, MD 20770; (301)441-8777.

March 14-16, The Next Generation of U.S. Agricultural Conservation Policy, sponsored by the Soil and Water Conservation Society, will be held in Kansas City, MO; contact SWCS, 7515 Northeast Ankeny Road, Ankeny, IA 50021-9764; 1800-THE SOIL. 